\title{
Detection of exopolysaccharide production and biofilm-related genes in Staphylococcus spp. isolated from a poultry processing plant
}

\author{
Andreza Angélica FERREIRA ${ }^{1 *}$, Patrícia Amaral Souza TETTE, Regina Célia Santos MENDONÇA, \\ Ariana de Souza SOARES ${ }^{1}$, Márcia MARIA DE CARVALHO ${ }^{1}$
}

\begin{abstract}
Staphylococcus spp. can survive in biofilms for long periods of time, and they can be transferred from one point to another and cause environmental contamination in food processing. The aim of this study was to detect Staphylococcus strains isolated from a poultry processing plant by the presence of adhesion genes and the phenotypic production of exopolysaccharide. In the present study, the production of exopolysaccharide and the presence of adhesion genes in 65 strains of Staphylococcus spp. were evaluated. All strains of Staphylococcus spp. produced exopolysaccharide, as confirmed by formation of black and opaque colonies in Congo Red Agar. The variation of sucrose content was critical for the production of exopolysaccharide in Congo Red Agar since at low sucrose concentrations all strains presented a characteristic result, i.e., there was no exopolysaccharide production. The atl gene was found in all strains, and the ica A and icaD genes were found in $97 \%$ of them. The data obtained suggest that Staphylococcus spp. isolated from the poultry processing plant evaluated has a potential for biofilm formation. An efficient control of this microorganism in food processing environment is necessary as they may represent a potential risk to consumers.
\end{abstract}

Keywords: Staphylococcus aureus; biofilm; adhesion genes; ica genes; Congo red agar.

\section{Introduction}

Several types of foods are indicated as the cause of gastrointestinal poisoning by $S$. aureus, often being related to the consumption of meat and its products because of their favorable water activity, $\mathrm{pH}$, and nutrient characteristics and extensive manipulation during processing (Ananou et al., 2005). This microorganism can remain viable in biofilms over long periods of time, and they can be transferred from one point to another and cause environmental contamination in food processing (Shale et al., 2005).

The cells released from cell aggregates or biofilms maintain high resistance to antimicrobial agents, and may contain sufficient numbers of bacteria to represent a potential infectious dose. Thus, it is assumed that cell aggregates or biofilm formation by $S$. aureus can be a potential risk for food cross-contamination (Souza et al., 2014).

The ability of $S$. aureus to produce biofilm represents an important virulence factor and is dependent on the environmental conditions, suggesting that there is a mechanism that detects and responds to environmental signals related to the expression of genes involved in adhesion processes (ToledoArana et al., 2005).

Several genes are involved in the production of staphylococcal biofilm formation (Cerca et al., 2008; Valle et al., 2003); however, the regulatory mechanisms are poorly understood (Rode et al., 2007). There is a consensus that the main determinants in the mechanism of biofilm formation by Staphylococcus are mediated by the production of capsular polysaccharide adhesin (PS/A) and intercellular polysaccharide adhesin (PIA) or poly- $\mathrm{N}$ succinyl- $\beta-1,6$-glucosamine, whose synthesis is encoded by the gene products of the locus ica operon of icaABCD (Yazdani et al., 2006; Stanley \& Lazazzera, 2004; Beenken et al., 2003).

The genes and products of the locus ica are considered critical for biofilm formation and virulence of the Staphylococcus genus, and they are regulated in response to environmental factors such as glucose, anaerobiosis, high osmolarity, high temperature, ethanol, and iron limitation (Yazdani et al., 2006). Several studies have reported higher frequency of distribution of the ica genes in Staphylococcus isolates from foods (Melo et al., 2013; Rumi et al., 2013; Ciftci et al., 2009; Rode et al., 2007; Møretrø et al., 2003).

Understanding the processes of biofilm formation by S. aureus can facilitate the study on the ability of wild strains to adhere and to form biofilms when they are exposed to conditions simulating the environments found in food processing plants, and it allows a better definition of control strategies (Souza et al., 2014).

PCR analysis only reveals the genetic predisposition for biofilm formation and expression of ica genes; thus, the real biofilm formation must be confirmed by additional phenotypic methods (Melo et al., 2013). The aim of this study was to detect Staphylococcus strains isolated from a poultry processing plant by the presence of adhesion genes and the phenotypic production of exopolysaccharide. 


\section{Materials and methods}

\subsection{Bacterial species}

Strains of Staphylococcus spp. belonging to the culture bank of the Food and Water Source Pathogen Microbiology Laboratory at the Federal University of Viçosa, Brazil (Table 1) were used in the present study.

\subsection{Phenotypic analysis of exopolysaccharide production}

Exopolysaccharide (EPS) production was assessed by cultivating the strains on Congo Red Agar (CRA) using a method modified by Freeman et al. (1989). The CRA allows the detection of exopolysaccharide production by variation in the color of colonies in the medium. The medium was prepared adding $0.8 \mathrm{~g}$ of the Congo red dye $\left(\mathrm{Merck}^{\circledR}\right)$ in $1 \mathrm{~L}$ of Brain and Heart Infusion Agar (BHI, Himedia ${ }^{\circledR}$ ) supplemented with different amounts of sucrose (50 g, $25 \mathrm{~g}, 12.5 \mathrm{~g}, 6.25 \mathrm{~g}$, and $3.13 \mathrm{~g}$ ) without the addition of sucrose to evaluate the influence of the concentration of sucrose on the phenotypic production of exopolysaccharide. The CRA proposed by Freeman et al. (1989) contains 50 g. $\mathrm{L}^{-1}$ of sucrose. The bacterial isolates were streaked onto Congo Red Agar plates and incubated at $37^{\circ} \mathrm{C}$ for 24 hours, followed by incubation at $25^{\circ} \mathrm{C}$ for 24 hours to evaluate the influence of temperature. The S. aureus (ATCC 25923) and S. epidermidis (ATCC 12228) strains were also used for control purposes, positive and negative, respectively.

In the present study, a six-color reference scale was used for a fine classification of colonies colors, according to Arciola et al. (2002). The six-color tones of the scale were as follows: very black; black; and almost black, which were considered as positive results, and Bordeaux; red; and very red; considered as negative results.

\subsection{Identification of adhesion genes}

\section{Genomic DNA extraction}

The isolates of Staphylococcus spp. were incubated in B.O.D. incubator $\left(\right.$ Fanem $\left.^{\circledR}\right)$ at $37^{\circ} \mathrm{C}$ for 18 hours in $5 \mathrm{~mL}$ of BHI syrup (Himedia ${ }^{\circledR}$ ). The DNA of the isolates was extracted from one milliliter of the bacterial culture, which was centrifuged (Jouan ${ }^{\circledR}$ $\mathrm{CR} 3 \mathrm{i}$ ) at $12000 \mathrm{x} \mathrm{g}$ at $4^{\circ} \mathrm{C}$ for 2 minutes. The supernatant was discarded, and $60 \mu \mathrm{L}$ of lysis solution (20\% sucrose, $\mathrm{Na}_{2} \mathrm{HPO}_{4}$ $0.01 \mathrm{~mol} / \mathrm{l}, \mathrm{pH} 7.0)$ and lysozyme $\left(\mathrm{USB}^{\circledR}\right)(0.1 \mathrm{~g} / \mathrm{ml}$ added at the moment of the extraction) were added to the sediment with incubation in water bath at $37^{\circ} \mathrm{C}$ for 1 hour. After that time, $3 \mu \mathrm{L}$ of K proteinase $\left(\right.$ Sigma $\left.^{\circledR}\right)(20 \mathrm{mg} / \mathrm{ml}), 507 \mathrm{ml}$ of 10:1 TE buffer (Tris-HCl $10 \mathrm{mmol} / \mathrm{l}, \mathrm{pH} 7.5$, EDTA $1 \mathrm{mmol} / \mathrm{l}$ ), $30 \mathrm{ml}$ of SDS $\left(\right.$ Amresco $\left.{ }^{\circledR}\right) 10 \%$ were added, mixed, and incubated at $37^{\circ} \mathrm{C}$ for 30 minutes. Later, $5 \mathrm{ml}$ of RNase $\left(\right.$ Sigma $\left.{ }^{\circledR}\right)$ were added and the tube containing the DNA extracted by the cells was incubated at $25{ }^{\circ} \mathrm{C}$ for 2 minutes; next, $100 \mathrm{ml}$ of $\mathrm{NaCl}\left(\mathrm{Vetec}^{\circledR}\right) 5 \mathrm{~mol} / \mathrm{l}$, $80 \mathrm{ml}$ of hexadecyltrimethylammonium (CTAB (Sigma $\left.{ }^{\circledR}\right) 2 \%$ : $0.7 \mathrm{M} \mathrm{NaCl}$ (1:1) were added, and the tube was incubated at $65^{\circ} \mathrm{C}$ for 10 minutes. Afterwards, $750 \mathrm{ml}$ of chloroform:isoamyl alcohol (24:1) were added, and the suspension was stirred for 1 minute and centrifuged $\left(\right.$ Jouan $^{\circledR}$ ) at $12000 \mathrm{x} g$ for 15 minutes. The supernatant was transferred to another tube, to which $750 \mathrm{ml}$ of chloroform: isoamyl alcohol (24:1) were added followed by centrifugation for 10 minutes. The supernatant was again transferred to another micro tube, to which approximately $500 \mathrm{ml}$ of $100 \%$ isopropanol were added and stored at $-20{ }^{\circ} \mathrm{C}$ for 18 hours. After that, it was again centrifuged at $12000 \mathrm{xg}$ for 15 minutes, and the supernatant was discarded; $1.5 \mathrm{ml}$ of $75 \%$ ethanol was added, mixed gently for 5 minutes, centrifuged again for 2 minutes, and the supernatant discarded. This procedure was repeated twice. The pellet was oven-dried at $37^{\circ} \mathrm{C}$ for $5 \mathrm{~min}\left(\right.$ Fanem $\left.^{\circledR}\right)$, and then added to $100 \mathrm{ml}$ of $10: 1$ TE buffer (Tris-HCl $10 \mathrm{mmol} / \mathrm{L}$, pH 7.5, EDTA $1 \mathrm{mmol} / \mathrm{L}$ ). The DNA was quantified using a spectrophotometer (Nanodrop $\left.{ }^{\circledR}\right)$.

\section{$P C R$ reaction for identification of the icaAD and atl genes}

The primers $\left(\right.$ Sigma $^{\circledR}$ ) used for the amplification of the icaD (F - GGA TCC TTA GTG TTA CAA TTT T; R - TGA CTT TTT GGT AAT TCA AGG TTG TC), icaA (F - TGA ACC GCT TGC CAT GTG; R - CAC GCG TTG CTT CCA AAG A) and atl (F - GCC TGT TGC AAA GTC AAC AA; R - CAC CGA CAC CCC AAG ATA AG) genes were reacted separately using the parameters modified for the amplification by Korem et al. (2010), Rode et al. (2007), McLaughlin \& Hoogewerf, (2006),

Table 1. List of strains of Staphylococcus spp. evaluated.

\begin{tabular}{|c|c|c|c|c|}
\hline \multirow{2}{*}{ Strain (s) } & \multirow{2}{*}{ Number } & \multicolumn{2}{|c|}{ Coagulase } & \multirow{2}{*}{ Origin } \\
\hline & & positive & negative & \\
\hline Staphylococcus aureus & 35 & 22 & 13 & Manipulator $^{\mathrm{a}}$ \\
\hline Staphylococcus aureus & 5 & 3 & 2 & Surface $^{\mathrm{b}}$ \\
\hline Staphylococcus aureus & 14 & 12 & 2 & Poultry carcass ${ }^{c}$ \\
\hline Staphylococcus aureus & 4 & 4 & - & Utensil $^{\mathrm{d}}$ \\
\hline Staphylococcus spp. & 3 & 1 & 2 & Manipulator $^{\mathrm{a}}$ \\
\hline Staphylococcus spp. & 1 & 1 & - & Surface $^{\mathrm{b}}$ \\
\hline Staphylococcus spp. & 3 & 3 & - & Utensil $^{\mathrm{d}}$ \\
\hline
\end{tabular}

Reference Strains

Staphylococcus aureus (ATCC 6538)

Staphylococcus aureus (ATCC 25923)

Staphylococcus epidermidis (ATCC12228)

Strains isolated from: ${ }^{\mathrm{a}}$ hands of handlers of a poultry slaughterhouse; ${ }^{\mathrm{b}}$ AISI 304 stainless steel surfaces; ${ }^{\mathrm{c}}$ poultry carcass; ${ }^{\mathrm{d}}$ plates and knives used in the poultry slaughterhouse 
respectively. The reactions consisted of a mixture of $0.4 \mathrm{mmol} / \mathrm{l}$ of each primer, $0.3 \mathrm{mmol} / \mathrm{ldNTP}, 1.5 \mathrm{mM}$ of $\mathrm{MgCl} 2,1 \mathrm{x}$ of buffer of Taq DNA polymerase (Promega $\left.{ }^{\circledR}\right)$ enzyme, $1 \mu \mathrm{l}(50 \mathrm{ng})$ of the genomic DNA, and $1 \mathrm{U}$ of Taq DNA polymerase (Promega ${ }^{\circledR}$ ) to a final volume of $25 \mathrm{ml}$. The reaction was conducted using a thermal cycler $\left(\right.$ Axigen $^{\circledR}$ ) and the amplification conditions consisted of a denaturation step at $94^{\circ} \mathrm{C}$ for $5 \mathrm{~min}$, followed by 30 thermal cycles of $94^{\circ} \mathrm{C}$ for 30 seconds, $55^{\circ} \mathrm{C}$ for 30 seconds and $72{ }^{\circ} \mathrm{C}$ for 30 seconds, with a final extension step at $72{ }^{\circ} \mathrm{C}$ for $5 \mathrm{~min}$. A S. aureus (ATCC 6538) strain was used as positive control. Five microliters of the amplified product were visualized in a transilluminator using a Quantum ST4 - 1000/26mX gel documentation system after conducting electrophoresis with $1 \%$ agarose gel. A $100 \mathrm{pb}$ molecular marker $\left(\right.$ BioLabs $\left.^{\circledR}\right)$ was used.

\section{Results}

\subsection{Phenotypic assay for detection of the exopolysaccharide production}

All strains tested positive for production of EPS because they formed black and opaque colonies on Congo Red Agar (CRA) with $50 \mathrm{~g} / \mathrm{l}$ of sucrose in the first 24 hours of incubation. After 24 hours, the black colonies became reddish (center). However, they are still considered positive as almost black colonies, according to the colorimetric scale proposed by Arciola et al. (2002) (Figure 1).
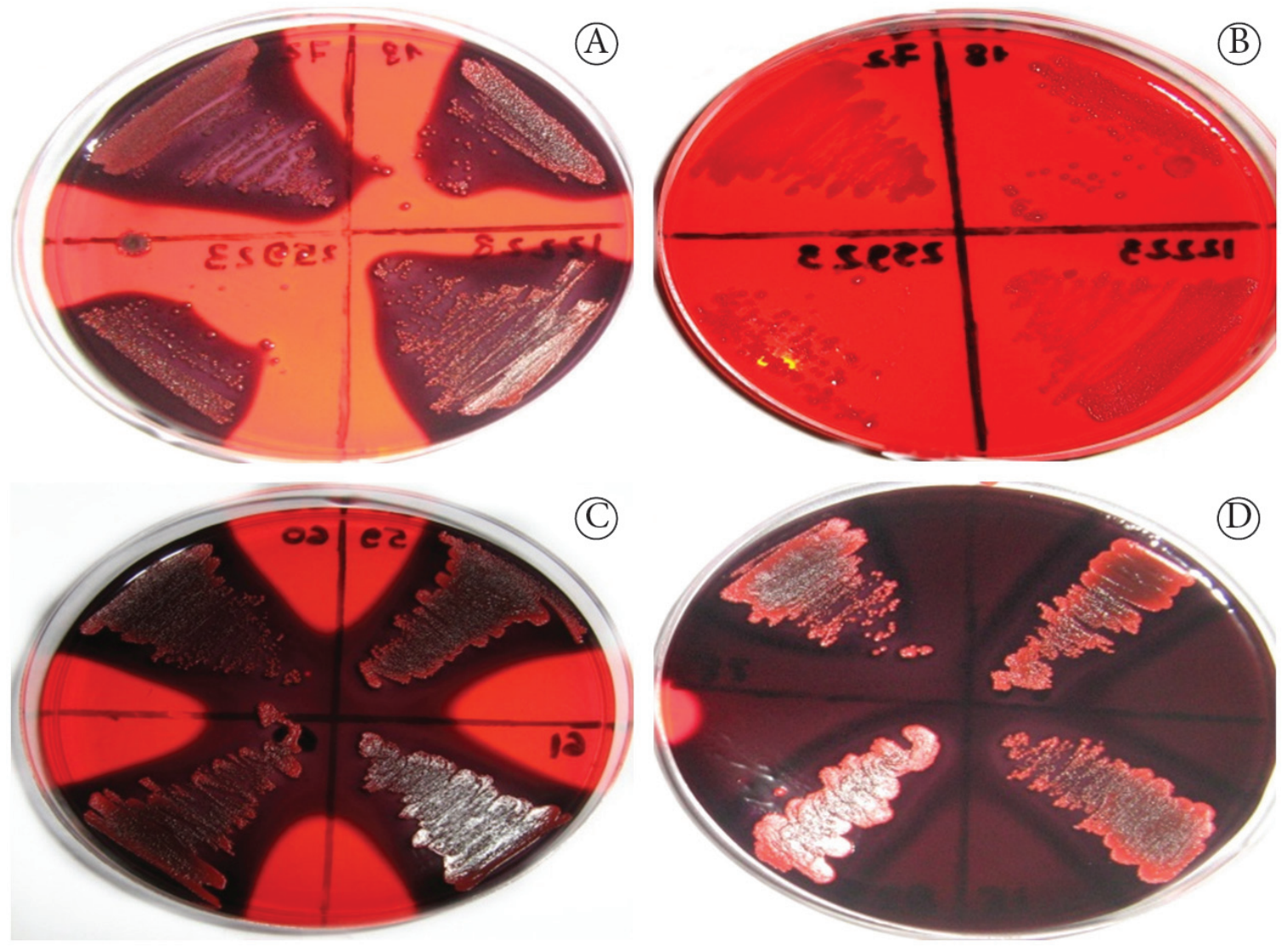

Figure 1. Colonies of Staphylococcus strains producing exopolysaccharide on Congo red agar with $50 \mathrm{~g} / \mathrm{l}$ of sucrose. A - black or almost black colonies (positive), B - red and smooth colonies (negative), C - positive colonies after 24 hours of incubation, D - positive colonies after 48 hours of incubation. 

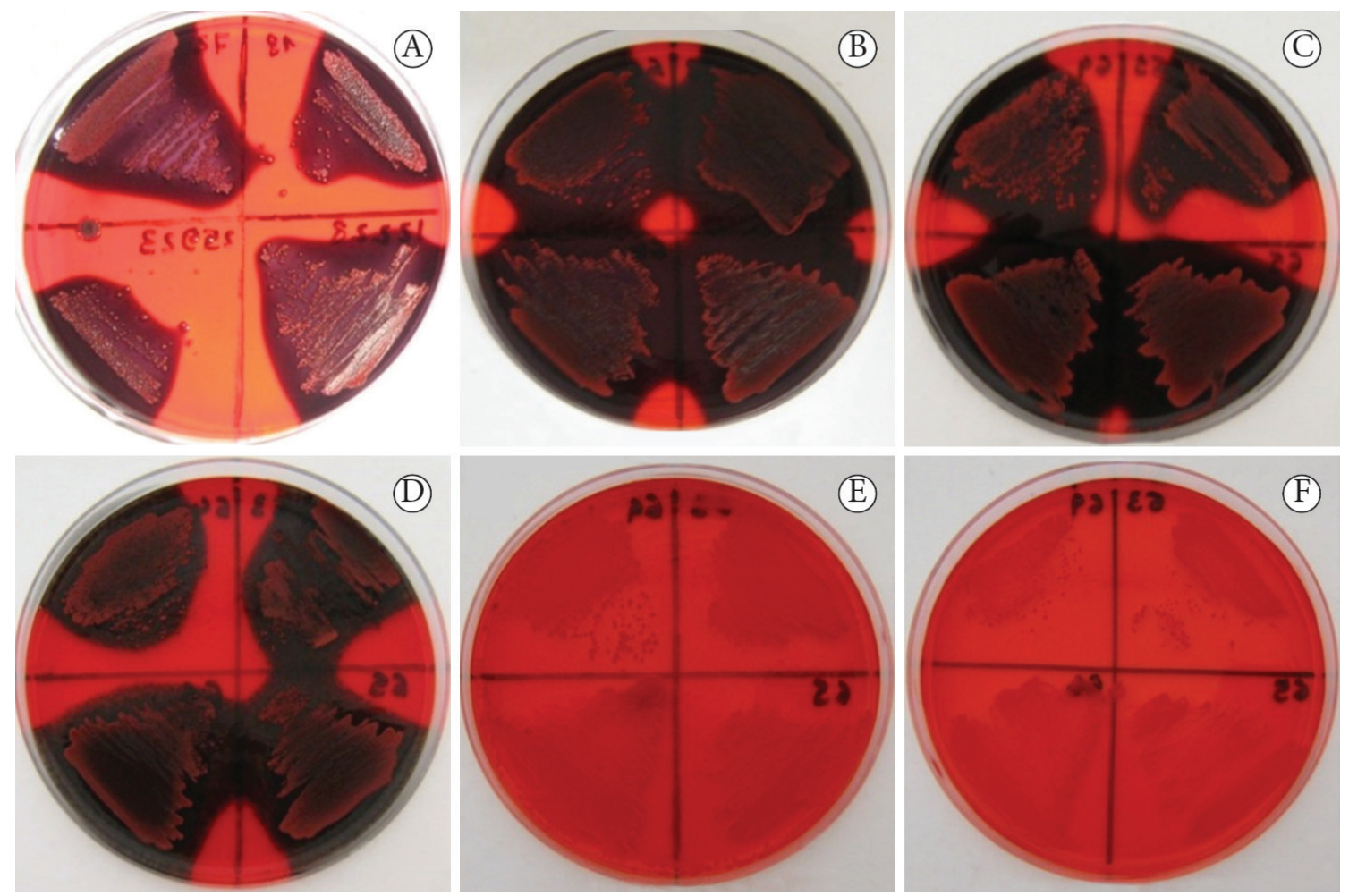

Figure 2. Production of exopolysaccharide according to the sucrose content of the Congo red agar. A - $50 \mathrm{~g} / \mathrm{l}$ of sucrose, B - $25 \mathrm{~g} / \mathrm{l}$ of sucrose, C - $12.5 \mathrm{~g} / \mathrm{l}$ of sucrose, D - $6.25 \mathrm{~g} / \mathrm{l}$ of sucrose, E - $3.13 \mathrm{~g} / \mathrm{l}$ of sucrose, and F - without sucrose.
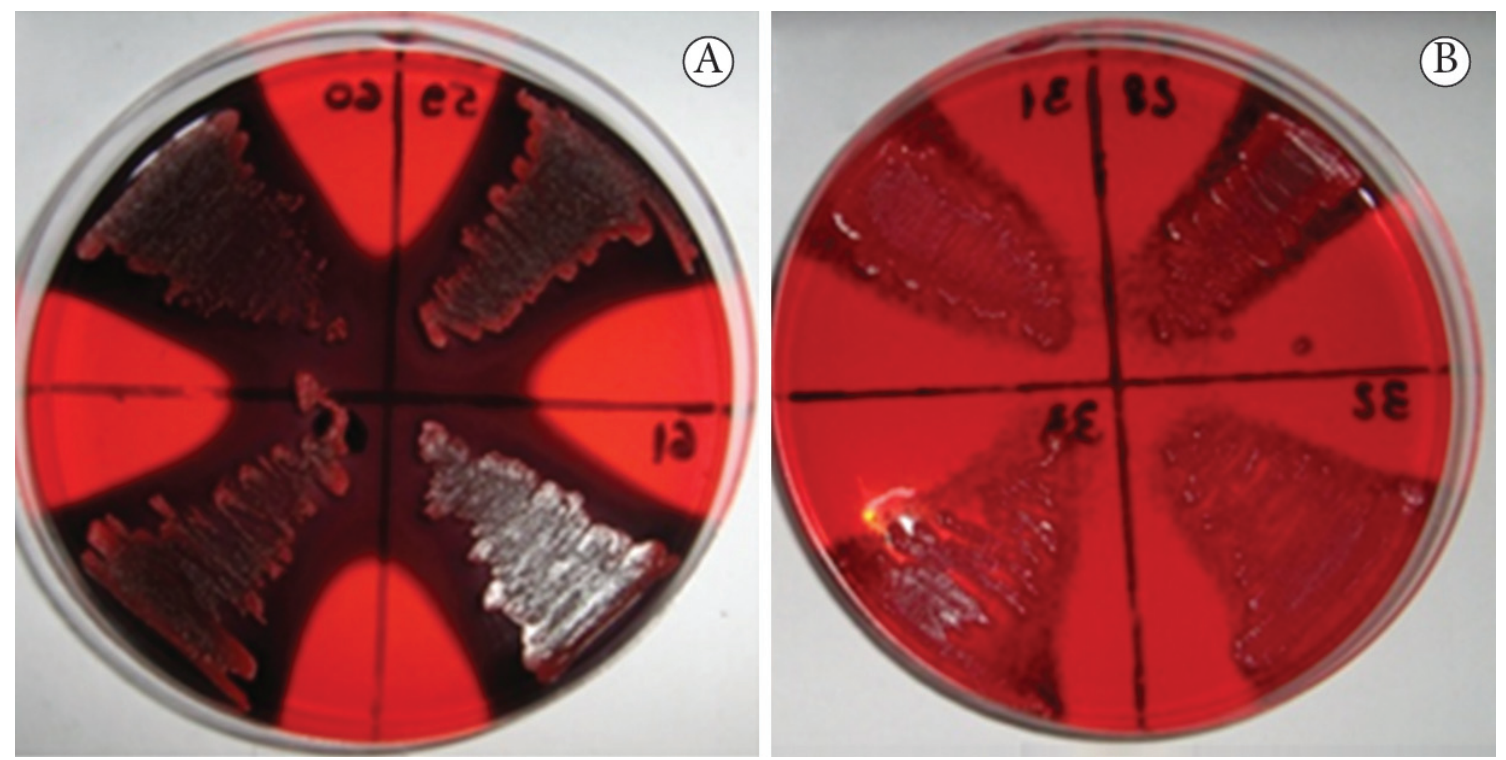

Figure 3. Reduction in the diffusivity of dark pigments at the concentration of $6.25 \mathrm{~g} / \mathrm{l}$ sucrose. A - 24 hours of incubation, B - 48 hours of incubation.

This result demonstrates that the concentration of a carbon source can limit the gene expression involved in the production of PIA and PS/A. Researchers suggest that the PIA synthesis can be regulated by the presence of a carbohydrate source in the medium that expresses positive phenotypes in biofilm formation in Staphylococcus (Dobinsky et al., 2003; Baldassarri et al., 2001; Rachid et al., 2000).

The biofilm formation by strains of $S$. aureus can be affected by environmental conditions relevant for the food industry due to the constant presence of carbohydrate residues formed during processing.

The phenotypic production of EPS by icaAD-negative strains used in the present study suggests that staphylococcal biofilm development may have occurred via an ica-independent pathway. According to O'Gara (2007), the atl gene, plays an important role in the primary attachment phase of biofilm development. The atl gene was present in all strains evaluated. This alternative mechanism of biofilm synthesis relies on the 
(A)
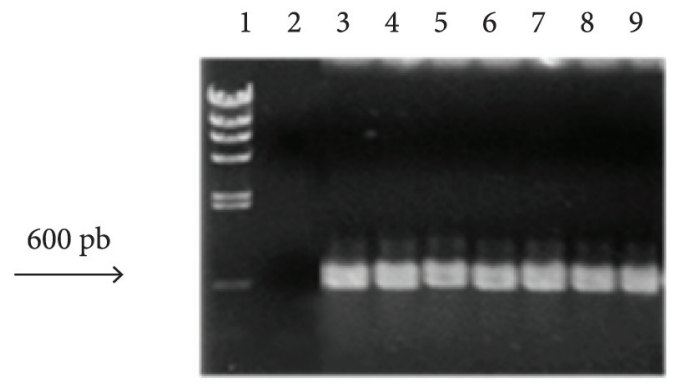

(B)
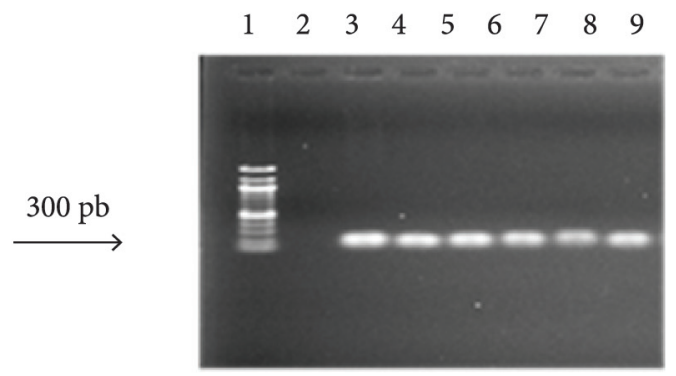

(C)

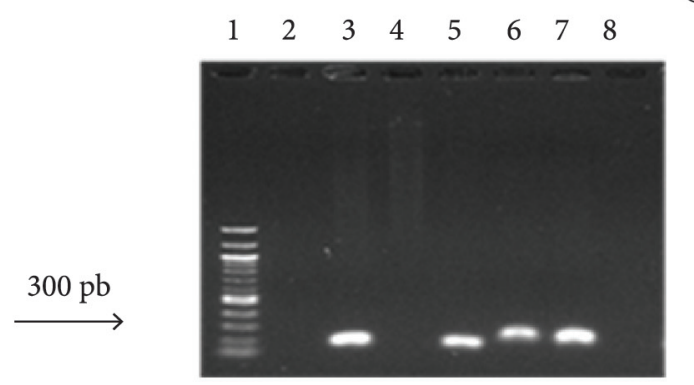

Figure 4. Molecular identification of genes involved in the adhesion of Staphylococcus spp. A - Molecular identification of the atl gene (Line 1: molecular marker; Line 2: negative control; Line 3 to line 9: positive results), B - Molecular identification of icaA gene (Line1: molecular marker; Line 2: negative control; Line 3 to line 9: positive results), C - Molecular Identification of icaD gene (Line 1: molecular marker; Line 2: negative control; Lines 3: positive result; Line 4: negative result; Line 5 to line 7: positive results; Line 8: negative result).

ability of $S$. aureus to express a variety of adhesion proteins that allows cells to attach and to colonize a large number of different surfaces.

Furthermore, it cannot be determined, based on the detection of only one ica gene, whether the strain has the potential to produce biofilm since there is a genetic variation among Staphylococcus strains.

Møretrø et al. (2003) suggest that it is more appropriate to use the biofilm formation and not the presence or absence of the locus ica as one of the criteria for determining potentially virulent strains because biofilm formation on inert surfaces is highly sensitive to environmental and nutritional conditions, such as the presence of ethanol, iron, varying glucose and sodium chloride concentrations, among others. Kaiser et al. (2013) developed a new CRA formula containing glucose, sodium chloride, and vancomycin, and they confirmed the capacity to detect biofilm in 210 S. epidermidis strains isolates, including only $76(36.2 \%)$ icaAB gene-positives strains. The use of glucose or sodium chloride or combination of both enhances biofilm producing capacity of staphylococcal isolates irrespective of the presence or absence of ica operon (Agarwal \& Jain, 2013).

This demonstrates that one should be careful before drawing general conclusions about gene presence in S. aureus when it comes to biofilm formation. The results are relevant for food safety as they indicate that food processing conditions could promote biofilm formation by $S$. aureus regardless of the expression of ica genes.

The mechanisms involved in the transcriptional regulation of the ica locus are only partially understood, and different regulatory mechanisms are known for S. aureus and S. epidermidis (Arciola et al., 2012).

The high prevalence of EPS production by the tested strains in this study emphasizes the responsibility of professionals involved in the food production chain to adopt hygienic and sanitary measures since the formation of biofilm in the industrial environment by Staphylococcus spp. should occur within hours. Accordingly, the increasing automation of the industries and the employment of sophisticated equipment can complicate the cleaning process and create a large number of niches for the adhesion and multiplication of microorganisms, which contribute to biofilms formation with consequent impairment of food safety and equipment efficiency.

Some studies have evaluated the effect of different growth conditions on the adherence and biofilm formation of $S$. aureus isolates in food industries. The assayed strains revealed high capacities to adhere and form biofilms on polypropylene and stainless steel surfaces under different growth conditions, and the cells in biofilm matrixes were resistant to total removal when exposed to the sanitizers such as sodium hypochlorite and peracetic acid (Souza et al., 2014; Jerônimo et al., 2012).

Several studies have reported a higher frequency of distribution of the ica genes and slime production in Staphylococcus isolates from milk (Melo et al., 2013; Rumi et al., 2013; Ciftci et al., 2009), meat, and contact surfaces in processing plants (Schlegelová et al., 2008), indicating the virulence potential of the strains evaluated.

The combination of phenotypic and genotypic methods employed in the present study allowed the screening of strains potentially capable of expressing biofilm-forming Staphylococcus genus genes. Nevertheless, there is still a need for further studies on regulatory mechanisms of biofilm formation by Staphylococcus in the processing environment, mainly owing to genetic variations between the strains evaluated. Thus, professionals involved in food production should be aware of the importance of controlling biofilm formation by Staphylococcus and that it can occur under conditions commonly used in the food industry representing a potential risk to consumers. 


\section{References}

Agarwal, A., \& Jain, A. (2013). Glucose \& sodium chloride induced biofilm production \& ica operon in clinical isolates of staphylococci. The Indian Journal of Medical Research, 138, 262266. PMid:24056605.

Ananou, S., Maqueda, M., Martínez-Bueno, M., Gálvez, A., \& Valdivia, E. (2005). Control of Staphylococcus aureus in sausages by enterocin AS-48. Meat Science, 71(3), 549-556. http://dx.doi.org/10.1016/j. meatsci.2005.04.039. PMid:22060932

Arciola, C. R., Campoccia, D., Speziale, P., Montanaro, L., \& Costerton, J. W. (2012). Biofilm formation in Staphylococcus implant infections. A review of molecular mechanisms and implications for biofilm-resistant materials. Biomaterials, 33(26), 5967-5982. http:// dx.doi.org/10.1016/j.biomaterials.2012.05.031. PMid:22695065

Arciola, C. R., Campoccia, D., Gamberini, S., Cervellati, M., Donati, E., \& Montanaro, L. (2002). Detection of slime production by means of an optimised Congo red agar plate test based on a colourimetric scale in Staphylococcus epidermidis clinical isolates genotyped for ica locus. Biomaterials, 23(21), 4233-4239. http://dx.doi.org/10.1016/ S0142-9612(02)00171-0. PMid:12194526

Baldassarri, L., Bertuccini, L., Ammendolia, M. G., Arciola, C. R., \& Montanaro, L. (2001). Effect of iron limitation on slime production by Staphylococcus aureus. European Journal of Clinical Microbiology \& Infectious Diseases, 20(5), 343-345. http://dx.doi.org/10.1007/ PL00011274. PMid:11453596

Beenken, K. E., Blevins, J. S., \& Smeltzer, M. S. (2003). Mutation of sarA in Staphylococcus aureus limits biofilm formation. Infection and Immunity, 71(7), 4206-4211. http://dx.doi.org/10.1128/ IAI.71.7.4206-4211.2003. PMid:12819120

Cerca, N., Brooks, J. L., \& Jefferson, K. K. (2008). Regulation of the intercellular adhesin locus regulator (icaR) by SarA, sigmaB, and IcaR in Staphylococcus aureus. Journal of Bacteriology, 190(19), 6530-6533. http://dx.doi.org/10.1128/JB.00482-08. PMid:18658265

Ciftci, A., Findik, A., Onuk, E. E., \& Savasan, S. (2009). Detection of methicillin resistance and slime factor production of Staphylococcus aureus in bovine mastitis. Brazilian Journal of Microbiology, 40(2), 254-261. http://dx.doi.org/10.1590/S1517-83822009000200009. PMid:24031354

Dobinsky, S., Kiel, K., Rohde, H., Bartscht, K., Knobloch, J. K. M., Horstkotte, M. A., \& Mack, D. (2003). Glucose-related dissociation between icaADBC transcription and biofilm expression by Staphylococcus epidermidis: evidence for an additional factor required for polysaccharide intercellular adhesin synthesis. Journal of Bacteriology, 185(9), 2879-2886. http://dx.doi.org/10.1128/ JB.185.9.2879-2886.2003. PMid:12700267

Freeman, D. J., Falkiner, F. R., \& Keane, C. T. (1989). New method for detecting slime production by coagulase negative staphylococci. Journal of Clinical Pathology, 42(8), 872-874. http://dx.doi. org/10.1136/jcp.42.8.872. PMid:2475530

Jerônimo, H. M. A., Queiroga, R. C. R. E., Costa, A. C. V., Barbosa, I. M., Conceição, M. L., \& Souza, E. L. (2012). Adhesion and biofilm formation by Staphylococcus aureus from food processing plants as affected by growth medium, surface type and incubation temperature. Brazilian Journal of Pharmaceutical Sciences, 48(4), 737-745. http://dx.doi.org/10.1590/S1984-82502012000400018.

Kaiser, T. D. L., Pereira, E. M., Santos, K. R., Maciel, E. L. N., Schuenck, R. P., \& Nunes, A. P. F. (2013). Modification of the Congo red agar method to detect biofilm production by Staphylococcus epidermidis. Diagnostic Microbiology and Infectious Disease, 75(3), 235-239. http://dx.doi.org/10.1016/j.diagmicrobio.2012.11.014. PMid:23313084
Korem, M., Gov, Y., \& Rosenberg, M. (2010). Global gene expression in Staphylococcus aureus following exposure to alcohol. Microbial Pathogenesis, 48(2), 74-84. http://dx.doi.org/10.1016/j. micpath.2009.11.002. PMid:19900530

McLaughlin, R. A., \& Hoogewerf, A. J. (2006). Interleukin-1 $\beta$-induced growth enhancement of Staphylococcus aureus occurs in biofilm but not planktonic cultures. Microbial Pathogenesis, 41(2-3), 67-79. http://dx.doi.org/10.1016/j.micpath.2006.04.005. PMid:16769197

Melo, P. C., Ferreira, L. M., Nader Filho, A., Zafalon, L. F., Vicente, H. I. G., \& Souza, V. (2013). Comparison of methods for the detection of biofilm formation by Staphylococcus aureus isolated from bovine subclinical mastitis. Brazilian Journal of Microbiology, 44(1), 119-124. http://dx.doi.org/10.1590/S1517-83822013005000031. PMid:24159293

Møretrø, T., Hermansen, L., Holck, A. L., Sidhu, M. S., Rudi, K., \& Langsrud, S. (2003). Biofilm formation and the presence of the intercellular adhesion locus ica among staphylococci from food and food processing environments. Applied and Environmental Microbiology, 69(9), 5648-5655. http://dx.doi.org/10.1128/ AEM.69.9.5648-5655.2003. PMid:12957956

O'Gara, J. P. (2007). ica and beyond: biofilm mechanisms and regulation in Staphylococcus epidermidis and Staphylococcus aureus. FEMS Microbiology Letters, 270(2), 179-188. http://dx.doi.org/10.1111/ j.1574-6968.2007.00688.x. PMid:17419768

Rachid, S., Ohlsen, K., Wallner, U., Hacker, J., Hecker, M., \& Ziebuhr, W. (2000). Alternative transcription factor sigma(B) is involved in regulation of biofilm expression in a Staphylococcus aureus mucosal isolate. Journal of Bacteriology, 182(23), 6824-6826. http://dx.doi. org/10.1128/JB.182.23.6824-6826.2000. PMid:11073930

Rode, T. M., Langsrud, S., Holck, A., \& Møretrø, T. (2007). Different patterns of biofilm formation in Staphylococcus aureus under food-related stress conditions. International Journal of Food Microbiology, 116(3), 372-383. http://dx.doi.org/10.1016/j. ijfoodmicro.2007.02.017. PMid:17408792

Rumi, M. V., Huguet, M. J., Bentancor, A. B., \& Gentilini, E. R. (2013). The icaA gene in staphylococci from bovine mastitis. Journal of Infection in Developing Countries, 7(7), 556-560. http://dx.doi. org/10.3855/jidc.2670. PMid:23857391

Schlegelová, J., Babák, V., Holasová, M., \& Dendis, M. (2008). The biofilm-positive Staphylococcus epidermidis isolates in raw materials, foodstuffs and on contact surfaces in processing plants. Folia Microbiologica, 53(6), 500-504. http://dx.doi.org/10.1007/ s12223-008-0078-y. PMid:19381474

Shale, K., Lues, J. F. R., Venter, P., \& Buys, E. M. (2005). The distribution of Staphylococcus sp. on bovine meat from abattoir deboning rooms. Food Microbiology, 22(5), 433-438. http://dx.doi.org/10.1016/j. fm.2004.09.007.

Souza, E. L., Meira, Q. G. S., Barbosa, I. M., Athayde, A. J. A. A., Conceição, M. L., \& Siqueira Júnior, J. P. (2014). Biofilm formation by Staphylococcus aureus from food contact surfaces in a meatbased broth and sensitivity to sanitizers. Brazilian Journal of Microbiology, 45(1), 67-75. http://dx.doi.org/10.1590/S151783822014000100010. PMid:24948915

Stanley, N. R., \& Lazazzera, B. A. (2004). Environmental signals and regulatory pathways that influence biofilm formation. Molecular Microbiology, 52(4), 917-924. http://dx.doi.org/10.1111/j.13652958.2004.04036.x. PMid:15130114

Toledo-Arana, A., Merino, N., Vergara-Irigaray, M., Débarbouillé, M., Penadés, J. R., \& Lasa, I. (2005). Staphylococcus aureus develops an alternative, ica-independent biofilm in the absence of the arlRS two-component system. Journal of Bacteriology, 187(15), 5318-5329. http://dx.doi.org/10.1128/JB.187.15.5318-5329.2005. PMid:16030226 
Valle, J., Toledo-Arana, A., Berasain, C., Ghigo, J.-M., Amorena, B., Penadés, J. R., \& Lasa, I. (2003). SarA and not sigmaB is essential for biofilm development by Staphylococcus aureus. Molecular Microbiology, 48(4), 1075-1087. http://dx.doi.org/10.1046/j.13652958.2003.03493.x. PMid:12753197
Yazdani, R., Oshaghi, M., Havayi, A., Pishva, E., Salehi, R., Sadeghizadeh, M., \& Foroohesh, H. (2006). Detection of icaAD gene and biofilm formation in Staphylococcus aureus isolates from wound infections. Iranian Journal of Public Health, 35(2), 25-28. 